\title{
Ecology of Children's Career Development: A Review of the Literature
}

\section{ARTIGO ORIGINAL}

\author{
Maria do Ceu Taveira ${ }^{1}$ \\ Íris Martins Oliveira \\ Alexandra Mendes Araújo \\ Universidade do Minho
}

\begin{abstract}
Previous efforts to elaborate an organizing framework for the study of children's career development identified its main dimensions and processes. However, the existing literature on children's ecological subsystems is scarce. This article presents a literature review of the context of children's career development. Based on Bronfenbrenner's theory, 36 eligible articles covered the following subjects: the microsystems family and school; the mesosystems family-school/peer-school relations and antecedents of transitions; the exosystems parents' work situation, social class, curriculum and teachers' professional development; the macrosystems ethnicity and culture; and the chronosystems passage of time over the life-course and across generations. An ecological perspective can be included in an organizing framework of children's careers and support further research and intervention. Empirical and practical implications are discussed.
\end{abstract}

Keywords: career development, children, bioecological model

\section{Ecologia do Desenvolvimento Profissional das Crianças: Uma Revisão da Literatura}

\begin{abstract}
RESUMO - Esforços prévios para organizar um modelo organizador do estudo do desenvolvimento profissional das crianças têm identificado as suas principais dimensões e processos. Contudo, a literatura existente sobre os subsistemas ecológicos das crianças é escassa. Este artigo apresenta uma revisão da literatura sobre os contextos de desenvolvimento profissional das crianças. De acordo com a teoria de Bronfenbrenner, 36 artigos elegidos abordam: os microssistemas família e escola; os mesossistemas família-escola/pares-escola e antecedentes de transições; os exossistemas situação profissional parental, classe social, currículo e desenvolvimento profissional de professores; os macrossistemas etnia e cultura; e os cronossistemas passagem do tempo no ciclo vital e entre gerações. Uma perspetiva ecológica pode ser incluída em um modelo organizador do desenvolvimento profissional das crianças e apoiar ivestigações e intervenção futuras. Discutem-se implicações empíricas e práticas.
\end{abstract}

Palavras-chave: desenvolvimento profissional, crianças, modelo bioecológico

In the last decade, there has been a renewed interest in conceptualizing children's career results and correlates (Skorikov \& Patton, 2007). Common ground to this interest is a contemporary view of career development as a life-span process (Super, 1990). This interest is also sustained by the insecurity of current educational and labour contexts, which have led to the need for early and contextualized career interventions aimed at fostering career development and students' agency and soft skills throughout the school years (Lent, 2001; Repetto, Pena, Mudarra, \& Uribarri, 2007; Schultheiss, 2005).

Despite the increased attention to children's career development, the literature of this topic is still fragmented (Araújo \& Taveira, 2009; Watson \& McMahon, 2005), and therefore scholars have recognized there is a need for a framework for the study of children's career development (e.g., Schultheiss, 2008; Watson \& McMahon, 2005). Efforts to address this gap have been initiated, focusing on the main dimensions of children's career development (Hartung,

1 Endereço para correspondência: University of Minho, Campus de Gualtar, Braga, Portugal.4710-057.E-mail: ceuta@psi.uminho.pt
Porfeli, \& Vondracek, 2005; Skorikov \& Patton, 2007), how and what do children learn about work (Watson \& McMahon, 2005), and the stages of career reasoning (Howard \& Walsh, 2010). These are promising contributions for an organizing framework of children's career development, as they include multidimensional, learning-based and age-appropriate descriptions.

However, a systematic attention to the child's ecological systems seems to be lacking in the literature. This gap was recognized by Araújo and Taveira (2009), who suggested that the developmental-contextual career meta-theory (Vondracek, Lerner, \& Schulenberg, 1986), recently articulated with the living system framework (Vondracek, Ford, \& Porfeli, 2014), could serve the study of children's career development. The developmental-contextual metatheory could contribute for an organizing framework of children's career development by crediting its dynamics of change, the child's active role in his/her development, and the child-contexts interactions (Araújo \& Taveira, 2009). It could also articulate human and career development literatures, as developmental-contextualism presents a comprehensive view 
of both career and human development (Tinajero \& Páramo, 2012; Vondracek et al., 1986).

The developmental-contextual career meta-theory presents a convergent and ecological perspective of career development. Convergence in career perspectives is found in the widespread recognition of the importance of children's contextualized experiences in the development of career planning and choice. Psychoanalytic theories, such as those presented by Roe (1957) and Bordin (1984) were among the first to highlight the influence of parenting styles on the development of psychosocial skills and styles of behaviour, which are later expressed through occupational choices and career patterns.

Correspondence career perspectives also credited the relevance of the child's experiences in proximal contexts. Holland's (1985) theory suggested the development of personality, interests, values and skills is influenced by children's social exposition to different personality types and work environments across the RIASEC structure (Realistic, Investigative, Artistic, Social, Enterprising, and Conventional).

An interactive perspective of career development was also emphasized in career learning theories. Mitchell and Krumboltz's (1990) social learning approach to career decision-making suggested that the individual's behaviour repertoires are based on learning experiences, including the ones from childhood, while interacting with the environment. Social cognitive career theory (Lent, Hackett, \& Brown, 2004) also suggested that children's learning experiences inside and outside the family are important for the development of social cognitive career mechanisms.

Although these career perspectives have not explicitly focused on children's career development, they acknowledged the interactive nature and the continuity of career behaviour. A different case was made by developmental career perspectives, which explicitly described childhood as a unique moment for career development and the interactional nature of children's careers. Theories presented by Gottfredson (1981, 2005) and Super (1990) suggested that the child develops his/her self-concept by integrating concepts of power, gender and social class in a social self and by advancing in the self-identification with and selfdifferentiation from key-figures. The identification and differentiation processes generally start in the family with the same-sex parent and extend to figures accessible at school and in the community (Super, 1990). Self-concept development is related to a process of circumscription, based on the perceived inconsistency between one's social self and occupational alternatives (Gottfredson, 2005). These theories share a focus on qualitative change in careers, which is also assumed by developmental-contextualism.

The developmental-contextual career meta-theory (Vondrcek et al., 1986) expanded the aforementioned theoretical contributions by focusing on the person-insituation development. Person-in-situation experiences are the foundation for children's physiological, psychological, and affective reactions, which are included in cognitive behaviour episode schemas that are continuously revised and influence lifelong career behaviour and trajectories (Vondracek et al., 2014).
Based on the current state of affairs and on the potential of developmental-contextualism for the study of children's career behaviour and learning, this article presents a literature review of the contexts of children's career development. Brofenbrenner's (1979; Bronfenbrenner \& Morris, 1998) ecological systems theory served the organization of this literature review. The ecological systems theory assumes that the child is influenced and influences environmental contingences. These environmental contingences are structured in five ecological levels (Bronfenbrenner \& Morris, 1998) - the micro-, meso-, exo-, macro-, and chronosystems. The microsystem is a set of interpersonal relations experienced in face-to-face settings. The mesosystem includes two or more settings containing the developing person and jointly influencing his/her development. The exosystem includes settings that do not directly involve the person, but which occurrences affect or are affected by him/ her. The macrosystem includes cultural beliefs, political forces and life-styles that interact with the person. The chronosystem covers the passage of time over the life course and across historical periods. The ecological systems theory has been credited by the developmental-contextual career meta-theory, as it supports a focus on the individual-contexts mutual dynamics and enables an interactional understanding of individual differences in career behaviour and trajectories based on contextual opportunities and barriers (Vondracek \& Porfeli, 2002).

The ecological systems theory has proved to be a useful rational to organize literature reviews of topics such as family functioning (e.g., Bronfenbrenner, 1986), homophobic bullying (e.g., Hong \& Garbarino, 2012), and youth care services (e.g., Derksen, 2010). This theory has also been suggested as a relevant framework to study career development (Vondracek, 2004), but the empirical examples of such a potential have heavily relied on the study of adolescents' careers (e.g., Young, 1983).

\section{Searching and Eligibility Process}

Possible sources of data for this review were identified via searches of Elsevier, EBSCO, Pepsic, Sage, Scopus, and Springer databases, due to their catalogue of published articles in Career Psychology. The keywords career development and children were combined with others to cover the micro-, meso-, exo-, macro-, and chrono- ecological levels (Brofenbrenner, 1979; Bronfenbrenner \& Morris, 1998). Articles at the microsystem level were searched with the keywords microsystem, family, parents, teachers, peers, leisure, and extracurricular activities. To search for mesosystem-related studies the keywords mesosystem, multiple-setting participation, partnership, contexts relations and ecological transitions were used. For the exosystem, the keywords exosystem, social class, media, curriculum, consultancy, teachers' burnout, parents' work, job situation, and work-family conflict were included. To search for macrosystem influences, the keywords macrosystem, culture, ethnicity, work policies and economy were applied. Finally, the keywords chronosystem, time, generations, and change were used for the chronosystem search. 
This search resulted in the identification of fifty-nine journal articles. Inclusion and exclusion criteria were established to select the studies for this literature review. Inclusion criteria considered journal articles published in the last decade (from 2004 to 2014) in international peerreviewed journals and written in English and Portuguese. These criteria enabled a current state-of-art review and the selection of available published studies.

The exclusion criteria ruled out studies that did not explicitly cover career variables or that were conducted with samples older than 14 years. The first exclusion criteria enabled this review to focus on career development issues and allowed the exclusion of 14 articles (i.e., eight of microsystem, three of mesosystem, two of exosystem, one of chronosystem). The second criteria considered the chronological definition of childhood from birth to 14 years old (see Hartung et al., 2005) and ruled out nine articles (i.e., five of microsystem, three of exosystem, one of macrosystem). Although four articles (i.e., Fouad et al., 2010; Gonçalves \& Coimbra, 2007; Kuijpers, Meijers, \& Gundy, 2011; Schmitt-Wilson \& Welsh, 2012) did not mention their samples' age, they indicated that the participants were attending middle-school years. As middle-school years are covered in the childhood age scope, these articles were included. Three studies performed with mothers and teachers (i.e., Aguiar \& Conceição, 2011; Mouta \& Nascimento, 2008; Oketch, Mutisya, \& Sagwe, 2012) were also found and included in the review, as they highlighted the role of key-figures in children's careers.

A total of 36 articles were eligible for this review. These articles (a) were published in international electronic databases, during the last decade, (b) were written in English or Portuguese, (c) explicitly covered career variables and (d) were conducted with children and/or influencing key-figures.

Communalities, contradictions and complementarities between the studies' findings were identified. Evidence was organized according to the ecological levels in which the child is embedded (see table 1). As the individualcontexts mutual dynamics have been highlighted in the understanding of individual differences in career behaviour and trajectories (Vondracek \& Porfeli, 2002), the articles' reference to dynamics among the ecological levels and the child's personal variables were considered. In addition, the type of the reviewed studies and their research methods were synthetized to understand how the contexts of children's career development have been studied to date. This synthesis would also enable the examination of whether this field presents an unbalanced use of quantitative versus qualitative or mixed-method research designs, as it happens in more general career literature (Stead et al., 2012).

\section{Microsystem}

Research in this topic has covered mainly the family and school microsystems. The literature suggests that parents influence offspring's occupational knowledge, values, career exploration, aspirations and career self-efficacy expectations (Bryant et al., 2006; Whiston \& Keller, 2004). Parents' intentional conversations about work, positive work orientation and valences (i.e., one's experiences and emotions sustaining his/her approach or aversion to work) also seem to impact children's career exploration, perceived social support in career choices, assignment of meaning to work, positive expectations for their future, work motivation and valences (Gonçalves \& Coimbra, 2007; Porfeli, Ferrari, \& Nota, 2012; Porfeli, Wang, \& Hartung, 2008). Evidence also indicates that although parents' expectations do not vary for their female or male offspring (Creed, Conlon, \& Zimmer-Gembeck, 2007), fathers' occupations correlate with boys' aspirations for maletraditional occupations (Schuette, Ponton, \& Charlton, 2012). An authoritative parenting style has been also suggested to reinforce children's career exploration, which in turn impacts an increasingly differentiation of interests with grade (Tracey, Lent, Brown, Soresi, \& Nota, 2006).

Mutual interactions between the child and his/her mother have also been considered. Mothers' occupational expectations for their sons/daughters seem to be related to their general and reading abilities (Creed et al., 2007), while mother's high educational levels, job prestige, and emotionally enabling speech correlate with children's high academic and high status occupational aspirations (Fulcher, 2011; Tenenbaum, Porche, Snow, Tabors, \& Ross, 2007). Mothers' expectations for their offspring to hold gender nontraditional occupations have also been shown to correlate with children's favourable self-efficacy expectations and preferences for gender non-traditional school subjects (Fulcher, 2011). Still, findings about whether girls or boys present high self-efficacy expectations and preferences for gender non-traditional school subjects are controversial (e.g., Fulcher, 2011; Schuette et al., 2012).

At the school setting, children perceive teaching practices and teachers' encouragement, openness, and concern for their students' educational and occupational goals as supports for pursuing careers in science and mathematics. The awareness of environmental supports and barriers to one's career projects seems to vary with school levels, as middle-school children perceive more supports and fewer barriers than high-school students (Fouad et al., 2010). Teachers' childcentred practices also seem to promote students' interest for reading and mathematics, which can impact further academic and career choices. However, girls present more preferences for reading and fewer for numeracy than boys (Lerkkanen et al., 2012).

Focusing on teacher-child interactions, Bayraktar (2011) emphasizes the existence of gender-differentiated interactions in favour of girls, which may sustain their higher levels of perceived confidence and competence than boys in academic tasks, such as writing. This call to attention is even more relevant when additional evidence suggests that boys are more likely to dropout of school than girls and teachers' rating of boys' antisocial behaviours are associated with their poor academic achievement and school dropout, which can constitute a risk factor for discontinuities in careers (Ferreira, Santos, Fonseca, \& Haase, 2007). 
Table 1. Overview of the Eligible Articles

\begin{tabular}{|c|c|c|c|c|}
\hline Author(s) & Ecological level(s) & Type of article & Topic(s) covered & Research method(s) \\
\hline Aguiar and Conceição (2011) & Exosystem & Experience report & $\begin{array}{l}\text { Teachers' professional } \\
\text { development }\end{array}$ & $\begin{array}{l}\text { Qualitative procedures to evaluate } \\
\text { the experience }\end{array}$ \\
\hline $\begin{array}{l}\text { Anyadike-Danes and McVicar } \\
(2005)\end{array}$ & Mesosystem & Empirical study & Antecedents of adult work situation & $\begin{array}{l}\text { Quantitative retrospective } \\
\text { longitudinal sequence and } \\
\text { correlational methods }\end{array}$ \\
\hline Bayraktar (2011) & Microsystem & Empirical study & $\begin{array}{l}\text { Teacher-student interactions and } \\
\text { gender differences }\end{array}$ & $\begin{array}{l}\text { Mixed-method research design in } \\
\text { case studies }\end{array}$ \\
\hline Brown (2004) & $\begin{array}{l}\text { Exosystem and } \\
\text { macrosystem }\end{array}$ & Theoretical article & $\begin{array}{l}\text { Socioeconomic status and ethnicity } \\
\text { of the child's family }\end{array}$ & $\begin{array}{l}\text { Critical comments based on } \\
\text { published works }\end{array}$ \\
\hline $\begin{array}{l}\text { Bryant, Zvonkovic, and } \\
\text { Reynolds (2006) }\end{array}$ & Microsystem & Literature review & $\begin{array}{l}\text { Correlates of parenting variables } \\
\text { and career development processes }\end{array}$ & Review of published works \\
\hline $\begin{array}{l}\text { Creed, Conlon, and Zimmer- } \\
\text { Gembeck (2007) }\end{array}$ & Microsystem & Empirical study & $\begin{array}{l}\text { Parents' and children' career } \\
\text { aspirations and expectations }\end{array}$ & $\begin{array}{l}\text { Quantitative cross-sectional } \\
\text { prediction methods }\end{array}$ \\
\hline $\begin{array}{l}\text { Ek, Sovio, Remes, and Järvelin } \\
\text { (2005) }\end{array}$ & Mesosystem & Empirical study & $\begin{array}{l}\text { Antecedents of adult } \\
\text { unemployment }\end{array}$ & $\begin{array}{l}\text { Quantitative longitudinal } \\
\text { prediction methods }\end{array}$ \\
\hline $\begin{array}{l}\text { Ferreira, Santos, Fonseca, and } \\
\text { Haase (2007) }\end{array}$ & Exosystem & Empirical study & $\begin{array}{l}\text { Predictors of educational and } \\
\text { occupational socialization process }\end{array}$ & $\begin{array}{l}\text { Quantitative longitudinal } \\
\text { prediction methods }\end{array}$ \\
\hline Fouad et al. (2010) & Microsystem & Empirical study & $\begin{array}{l}\text { Barriers and supports to students' } \\
\text { careers }\end{array}$ & $\begin{array}{l}\text { Quantitative cross-sectional factor } \\
\text { methods }\end{array}$ \\
\hline Fulcher (2011) & Microsystem & Empirical study & $\begin{array}{l}\text { Mothers' influence on children's } \\
\text { self-efficacy expectations and } \\
\text { aspirations }\end{array}$ & $\begin{array}{l}\text { Quantitative cross-sectional } \\
\text { confirmatory methods }\end{array}$ \\
\hline Gonçalves and Coimbra (2007) & Microsystem & Empirical study & $\begin{array}{l}\text { Parents' influence in their offspring } \\
\text { career development }\end{array}$ & Qualitative and narrative methods \\
\hline Helwig (2004) & Chronosystem & Empirical study & $\begin{array}{l}\text { Passage of time over the life course } \\
\text { and career development }\end{array}$ & $\begin{array}{l}\text { Mixed-method longitudinal } \\
\text { research design }\end{array}$ \\
\hline Hirschi (2011) & Chronosystem & Empirical study & $\begin{array}{l}\text { Trajectories of career-choice } \\
\text { readiness }\end{array}$ & $\begin{array}{l}\text { Quantitative longitudinal } \\
\text { confirmatory methods }\end{array}$ \\
\hline $\begin{array}{l}\text { Howard, Ferrari, Nota, Solberg, } \\
\text { and Soresi (2009) }\end{array}$ & Mesosystem & Empirical study & $\begin{array}{l}\text { Supportive relationships in } \\
\text { children's career development }\end{array}$ & $\begin{array}{l}\text { Quantitative cross-sectional } \\
\text { confirmatory methods }\end{array}$ \\
\hline Hughes (2011) & Macrosystem & Empirical study & $\begin{array}{l}\text { Children's ethnical discrimination } \\
\text { awareness and aspirations }\end{array}$ & $\begin{array}{l}\text { Quantitative experimental } \\
\text { prediction methods }\end{array}$ \\
\hline $\begin{array}{l}\text { Kendig, Mattingly, and Bianchi, } \\
2014\end{array}$ & Exosystem & Empirical study & $\begin{array}{l}\text { Influence of childhood poverty in } \\
\text { adulthood }\end{array}$ & $\begin{array}{l}\text { Quantitative longitudinal mean } \\
\text { differences methods }\end{array}$ \\
\hline Kern and Friedman (2008) & Mesosystem & Empirical study & $\begin{array}{l}\text { Antecedents of later academic and } \\
\text { life adjustment }\end{array}$ & $\begin{array}{l}\text { Quantitative longitudinal } \\
\text { prediction methods }\end{array}$ \\
\hline Kingery and Erdley (2007) & Mesosystem & Empirical study & $\begin{array}{l}\text { Peers and children's academic } \\
\text { adjustment }\end{array}$ & $\begin{array}{l}\text { Quantitative longitudinal } \\
\text { prediction methods }\end{array}$ \\
\hline $\begin{array}{l}\text { Kuijpers, Meijers, and Gundy } \\
\text { (2011) }\end{array}$ & Exosystem & Empirical study & $\begin{array}{l}\text { Curriculum applications in } \\
\text { students' career competences }\end{array}$ & $\begin{array}{l}\text { Quantitative cross-sectional } \\
\text { prediction methods }\end{array}$ \\
\hline Lerkkanen et al. (2012) & Microsystem & Empirical study & $\begin{array}{l}\text { Influence of teachers' practices in } \\
\text { children's interest }\end{array}$ & $\begin{array}{l}\text { Quantitative longitudinal } \\
\text { confirmatory methods }\end{array}$ \\
\hline $\begin{array}{l}\text { Liu, McMahon, and Watson } \\
\text { (2014) }\end{array}$ & Macrosystem & Report & $\begin{array}{l}\text { Children's career development in } \\
\text { Mainland China }\end{array}$ & $\begin{array}{l}\text { Critical comments based on } \\
\text { published works }\end{array}$ \\
\hline Mouta and Nascimento (2008) & Exosystem & Experience report & $\begin{array}{l}\text { Teachers' professional } \\
\text { development }\end{array}$ & Notes about the experience \\
\hline Nazli (2007) & Mesosystem & Empirical study & $\begin{array}{l}\text { Description of children's career } \\
\text { development }\end{array}$ & $\begin{array}{l}\text { Qualitative exploratory-descriptive } \\
\text { methods }\end{array}$ \\
\hline Nazli (2014) & Macrosystem & Empirical study & $\begin{array}{l}\text { Turkish children's career } \\
\text { development }\end{array}$ & $\begin{array}{l}\text { Qualitative exploratory-descriptive } \\
\text { methods }\end{array}$ \\
\hline $\begin{array}{l}\text { Noack, Kracke, Gniewosz, and } \\
\text { Dietrich (2010) }\end{array}$ & Microsystem & Empirical study & $\begin{array}{l}\text { Family and school correlates of } \\
\text { students' career exploration }\end{array}$ & $\begin{array}{l}\text { Quantitative longitudinal } \\
\text { confirmatory methods }\end{array}$ \\
\hline $\begin{array}{l}\text { Oketch, Mutisya, and Sagwe } \\
\text { (2012) }\end{array}$ & Exosystem & Empirical study & $\begin{array}{l}\text { Slum and non-slum children's and } \\
\text { parents' aspirations }\end{array}$ & $\begin{array}{l}\text { Quantitative cross-sectional } \\
\text { prediction methods }\end{array}$ \\
\hline
\end{tabular}


Table 1. Overview of the Eligible Articles (cont.)

\begin{tabular}{|c|c|c|c|c|}
\hline Author(s) & Ecological level(s) & Type of article & Topic(s) covered & Research method(s) \\
\hline $\begin{array}{l}\text { Porfeli, Ferrari, and Nota } \\
\text { (2012) }\end{array}$ & Microsystem & Empirical study & $\begin{array}{l}\text { Family and children's work } \\
\text { valences }\end{array}$ & $\begin{array}{l}\text { Quantitative cross-sectional } \\
\text { confirmatory methods }\end{array}$ \\
\hline $\begin{array}{l}\text { Porfeli, Wang, and Hartung } \\
\text { (2008) }\end{array}$ & Microsystem & Empirical study & $\begin{array}{l}\text { Family work affectivityand the } \\
\text { socialization of children to work }\end{array}$ & $\begin{array}{l}\text { Quantitative cross-sectional } \\
\text { confirmatory methods }\end{array}$ \\
\hline $\begin{array}{l}\text { Schmitt-Wilson and Welsh } \\
\text { (2012) }\end{array}$ & Exosystem & Empirical study & $\begin{array}{l}\text { Vocational knowledge, academic } \\
\text { achievement, and occupational } \\
\text { aspirations of rural children }\end{array}$ & $\begin{array}{l}\text { Quantitative cross-sectional } \\
\text { prediction methods }\end{array}$ \\
\hline $\begin{array}{l}\text { Schoon, Martin, and Ross } \\
\text { (2007) }\end{array}$ & Chronosystem & Empirical study & $\begin{array}{l}\text { Cohort and historical time } \\
\text { differences in career development }\end{array}$ & $\begin{array}{l}\text { Quantitative cohort-sequential } \\
\text { longitudinal confirmatory methods }\end{array}$ \\
\hline $\begin{array}{l}\text { Schuette, Ponton, and Charlton } \\
\text { (2012) }\end{array}$ & Microsystem & Empirical study & $\begin{array}{l}\text { Parents' occupations and children's } \\
\text { aspirations }\end{array}$ & Mixed-method research design \\
\hline $\begin{array}{l}\text { Schultheiss, Palma, and Manzi } \\
(2005)\end{array}$ & Mesosystem & Empirical study & $\begin{array}{l}\text { Description of children's career } \\
\text { development }\end{array}$ & $\begin{array}{l}\text { Qualitative exploratory-descriptive } \\
\text { methods }\end{array}$ \\
\hline $\begin{array}{l}\text { Sobral, Gonçalves, and } \\
\text { Coimbra (2009) }\end{array}$ & Exosystem & Empirical study & $\begin{array}{l}\text { Parents' work situation and } \\
\text { offspring career development }\end{array}$ & $\begin{array}{l}\text { Quantitative cross-sectional mean } \\
\text { differences methods }\end{array}$ \\
\hline $\begin{array}{l}\text { Tenenbaum, Porche, Snow, } \\
\text { Tabors, and Ross (2007) }\end{array}$ & Microsystem & Empirical study & $\begin{array}{l}\text { Mother-child interactions and } \\
\text { children's academic engagement } \\
\text { and career intentions }\end{array}$ & $\begin{array}{l}\text { Quantitative longitudinal } \\
\text { prediction methods }\end{array}$ \\
\hline $\begin{array}{l}\text { Tracey, Lent, Brown, Soresi, } \\
\text { and Nota (2006) }\end{array}$ & Microsystem & Empirical study & $\begin{array}{l}\text { Parenting style and children's } \\
\text { career exploration and interests }\end{array}$ & $\begin{array}{l}\text { Quantitative longitudinal } \\
\text { confirmatory methods }\end{array}$ \\
\hline $\begin{array}{l}\text { Watson, McMahon, Foxcroft, } \\
\text { and Els (2010) }\end{array}$ & Macrosystem & Empirical study & $\begin{array}{l}\text { Occupational aspirations of Black } \\
\text { South-African children }\end{array}$ & $\begin{array}{l}\text { Qualitative exploratory-descriptive } \\
\text { methods }\end{array}$ \\
\hline
\end{tabular}

\section{Mesosystem}

The literature at the mesosystem level has focused on inter-relations among parents, teachers and peers as well as on antecedents of ecological transitions. From elementaryto middle-school years, children increasingly perceive their progress in career exploration, learning and planning as being influenced by their parents and teachers, who (a) help them acquire occupational information, (b) provide them social support, which is particularly important for girls, (c) help them identify possible occupations, (d) serve as role models, (e) offer opportunities to develop preferences, (f) shape their conceptions of work, (g) emphasize the role of education, and (h) instil life values (Nazli, 2007; Schultheiss, Palma, \& Manzi, 2005). Evidence also suggests that effective parenting and an acceptable school climate, as well as perceived social support from parents and teachers, facilitate children's career exploration and agency, being the latter important for academic achievement and career decidedness (Howard, Ferrari, Nota, Solberg, \& Soresi, 2009; Noack, Kracke, Gniewosz, \& Dietrich, 2010). Still, gender and grade differences have been found. The perception of teachers and peers' social support plays an important role in the development of girls- agency, who have also been shown to present higher levels of career exploration than boys (Howard et al., 2009; Noack et al., 2010). Additionally, eightgraders have been shown to present higher levels of career exploration compared to sixth-graders (Noack et al., 2010).

Research about ecological transitions has covered the childhood antecedents of the elementary- to middle-school transition and the transition to adult work and life adjustment. Peer acceptance, range of peers and friendship quality during elementary-school years were found to predict academic adjustment in middle-school years (Kingery \& Erdley, 2007). An on time or later school entry has also been shown to sustain high academic achievement in adolescence as well as mental health and reduced alcohol consumption in adulthood (Kern \& Friedman, 2008). Adult employment also seems to be preceded by high academic achievement, cognitive abilities and pro-social behaviours, mothers' high educational attainment and negative attitudes towards social aid, and fathers' employment during childhood (AnyadikeDanes \& McVicar, 2005; Ek, Sovio, Remes, \& Järvelin 2005).

\section{Exosystem}

Research at the exosystem level has focused on parents' work situation, social class, curriculum, and teachers' professional development. Evidence suggests that children whose parents are unemployed are at risk for diffusion and foreclosure of career options, being such a risk higher for boys than girls (Sobral, Gonçalves, \& Coimbra, 2009).

Social class has been covered in studies that describe rural children's career development and that contrast children from slum versus non-slum and poorer versus richer areas. Children from slum areas present lower academic aspirations than those from non-slum areas, being this difference also evident in parents' expectations for their offspring (Oketch et al., 2012). Children from poor families were also less likely to pursue college and more likely to become parents, start an independent life and help their families pay bills earlier in adulthood than children from richer areas (Kendig, Mattingly, \& Bianchi, 2014). Mothers' and fathers' socioeconomic status are also negatively related to patterns of dropping out of school and positive associations with career expectations 
and engagement in career projects (Ferreira et al., 2007; Sobral et al., 2009). The family's socioeconomic status can, therefore, influence family processes and careers (Brown, 2004). Additionally, research has suggested that rural students' academic achievement can facilitate their vocational knowledge, which in turn is related to high career aspirations and expectations (Schmitt-Wilson \& Welsh, 2012).

Kuijpers, Meijers, and Gundy (2011) found that teachers' dialogical curriculum applications were related to students' career reflection, forming and networking. This study also suggested that students' disposition for career reflection increased with grade and that while girls seemed to use more career dialogues and be more engaged in school than boys, the latter presented higher levels of networking than girls. Teachers can also influence children's career development by investing in their own professional development. Career consultancy practices with teachers appear not only to promote their professional development, but also their intentions to facilitate pupils' career exploration and development (Aguiar \& Conceição, 2011; Mouta \& Nascimento, 2008).

\section{Macrosystem}

Research about the macrosystem level has focused on ethnicity and culture. Although the literature seems to often confound the effects of ethnicity and socioeconomic status (Hartung et al., 2005), they are both implicated in the child's family dynamics (Brown, 2004). Vocational aspirations and interests have been studied with minority groups or with children subject to practices for ethnical discrimination awareness. Evidence on the former has suggested that gender differences of career interests differentiation are evident in Black South-African children. While Black South-African girls develop interests in Social and Artistic domains, boys prefer Investigative and Enterprising domains (Watson, McMahon, Foxcroft, \& Els, 2010). Research has also found that children's awareness of occupational ethnical discrimination is positively related to the gap between occupational aspirations and expectations. Non-ethnical biased workshops proved to be useful to reduce such a gap and to promote children's high status occupational expectations (Hughes, 2011).

Focusing on the role of culture, the study conducted by Mello (2009) showed that African-American and Asian-American children present higher educational and occupational expectations than European-American, Hispanic, or American-Indian children. Moving apart from Western cultures, Liu, McMahon, and Watson (2014) suggested that the Chinese culture stimulates children's awareness of the role of education for their futures and intentions to pursue occupations not only aligned with social expectations for gender but also capable of bringing honour to themselves and their families. As Chinese children present high status occupational aspirations but limited future time perspective and career planning, Liu and collaborators call for early career practices supported by Chinese policies. Similar suggestions were presented in Turkey, where children present favourable self-awareness and information about the world of work, but limited career planning, articulations of school experiences and careers, and knowledge about lifestyles related to occupations (Nazli, 2014).

\section{Chronosystem}

Research about the chronosystem focuses on the passage of time over the life course and across generations. Helwig (2004) provided empirical support to Gottfredson's (1981, 2005) theory, by showing that from elementary- to highschool, individuals crystalize gender-typified beliefs and increase the realism and social value of career exploration. On the other hand, Hirschi (2011) found that favourable generalized self-efficacy expectations and perception of few environmental barriers during childhood precede high career-choice readiness in adolescence. Developmental increases in career-choice readiness from childhood through adolescence also followed increases of information about the self and occupations.

Focusing on the passage of time across generations, Schoon, Martin, and Ross (2007) compared longitudinal data from two cohorts of British youth: one from 1958, who transited to the working world in a period of economic security and growth; and another from 1970, who entered the labour market in a time of economic recession. This study indicated that while favourable parental expectations were related to the first cohort's higher aspirations, school motivation and educational attainment, the economic disadvantage sustained individuals' lower school motivation and academic performance in the second cohort. In both cohorts, girls presented higher levels of school engagement and career planning than boys, although the employment outlook upon parenthood was more favourable for men.

\section{Discussion}

Following efforts to advance an organizing framework for the study of children's career development, this article presented a literature review of the contexts of children's career development. The focus on children's ecology of career development is sustained by the more general career literature, which suggests the importance of early interactional experiences in career behaviour (Bordin, 1984; Gottfredson, 1981, 2005; Holland, 1985; Lent et al., 2004; Mitchell \& Krumboltz, 1990; Roe, 1957; Super, 1980, 1990; Vondracek et al., 1986; Vondracek et al., 2014). This ecological organization also followed suggestions to apply the developmental-contextual career meta-theory to the study of children's careers (Araújo \& Taveira, 2009) and to identify their ecological subsystems (Vondracek, 2004). Moreover, the present literature review furthered the illustration of the potential of Brofenbrenner's (1979; Bronfenbrenner \& Morris, 1998) ecological systems theory to study adolescents' career development (e.g., Young, 1983), to cover this same process earlier in the lifespan.

The potential of the ecological systems theory to study children's careers led to a description of the child as an open system establishing mutual interactions with micro, meso, 
exo, macro and chronosystems. Throughout this review, the child-contexts mutual interactions were illustrated when gender and grade were covered. Research and practice need to consider specific career needs of girls and boys, including for example, girls' networking skills that might facilitate their future employment, and boys' academic experiences, career exploration, planning and coping with male social expectations (Ferreira et al., 2007; Kuijpers et al., 2011; Liu et al., 2014; Schoon et al., 2007). Further research on gender differences in self-efficacy expectations and preferences for gender non-traditional domains is also needed, as findings are controversial regarding this topic (e.g., Fulcher, 2011; Schuette et al., 2012). Future studies might explore relations among types of personality/work environments to which children are exposed (Holland, 1985) with their preferences and self-efficacy expectations in gender non-traditional domains. Practices pertaining to expand children's exposition to different personality/work environments might be considered. The literature has also suggested that increasing school levels interact with changes in career dimensions and children's perceptions about contextual barriers and supports to their careers (Fouad et al., 2010; Noack et al., 2010; Tracey et al., 2006). Further longitudinal studies might cover the processes and correlates of change in career development throughout the school years. Such studies might support grade-appropriate career interventions and promote student's agency and hope towards the future (Lent, 2001; Repetto et al., 2007; Schultheiss, 2005, 2008). These interventions should target not only the mesosystem level, by creating conditions for effective parenting, an open-school climate and supporting the provision of social support from key figures (e.g., Howard et al., 2009; Noack et al., 2006), but also the macrosystem level, by facilitating a multi-ethnical approach to careers and articulations between school and work (e.g., Hughes, 2011; Liu et al., 2014; Nazli, 2014).

Research at the microsystem level highlights the role of parents in children's career development (e.g., Bryant et al., 2006; Whiston \& Keller, 2004). As the parents' socialization roles are embedded in other ecological subsystems, this research topic might benefit from a systemic view of the family articulating its dynamics with ethnicity, socioeconomic status, culture, and historical periods (Brown, 2004; Bryant et al., 2006; Schoon et al., 2007). Future studies moving from a focus on mothers' (e.g., Creed et al., 2007; Fulcher, 2011; Tenenbaum et al., 2007) to fathers', siblings' and other family members' influences in children's careers are also encouraged. Given the lack of attention to peers, future microsystem research could also cover their role by assuming the neighbourhood, leisure and extracurricular settings as important environments for children's development and learning. Although the microsystem literature acknowledges the importance of teachers for children's career development, this research topic may further explore relations among teachers' characteristics (e.g., gender, educational level, teaching practices) and children's careers. These studies might explore the possible mediator role of teacher-student interactions and a possible moderator role of students' gender (e.g., Bayraktar, 2011). Other ecological levels such as the exosystem (e.g., schools' mission) and the macrosystem (e.g., governmental policies) can also be considered.
The literature at the mesosystem level suggests the positive impact of family and school's combined efforts on children's career exploration, agency, and awareness of the importance of key figures (Howard et al., 2009; Nazli 2007; Noack et al., 2010; Schultheiss, 2005). Research expanding the role of peers in children's career development can also enrich the mesosystem literature, by considering their articulations with other micro-settings. Evidence of childhood antecedents of later academic and life adjustment illustrates the potential of combining both the mesosystem and the chronosystem levels to address (dis)continuities in career trajectories. Conducting research in this line of inquiry may ultimately contribute for the identification of individuals at risk for maladaptive coping with ecological transitions, and who might benefit from preventive career interventions.

Research at the exosystem level has focused on the career development of children from poor social class. Although these children seem to present low academic aspirations and high risk for school dropout (Ferreira et al., 2007; Kendig et al., 2014; Oketch et al., 2012), academic achievement was found to buffer these effects (Schmitt-Wilson \& Welsh, 2012). The identification of other protective factors can be useful to design interventions aimed at attenuating social differences in children's careers (Schultheiss, 2005). Career interventions combining effective teachers' practices, curriculum applications (e.g., Kuijpers et al., 2011) and teachers' professional development (e.g., Aguiar \& Conceição, 2011; Mouta \& Nascimento, 2008) might promote the academic achievement and career development of children from poor social classes. Evidence at this ecological level also supports the need to examine the impact of parents' short- or long-term unemployment (AnyadikeDanes \& McVicar, 2005) on their offspring's careers. These empirical efforts might inform practices with unemployed people and their children, by acknowledging the indirect influence of parents' unemployment in children's careers (e.g., Sobral et al., 2009).

Literature at the macrosystem level suggests that despite cultural particularities, the articulation of school experiences with careers and the promotion of children's career development throughout the school years seem to constitute a worldwide concern (Liu et al., 2014; Nazli, 2014). Moreover, due to the challenges of the current educational and work environments, there is a need for promoting children's awareness of occupational ethnical diversity, so that individuals can cope with globalized multi-ethnic work environments and reduce the gap between their occupational aspirations and expectations (e.g., Hughes, 2011).

Finally, research at the chronosystem level yields a comprehensive view of career development as a process of time-related and time-extended change (Vondracek et al., 1986). Further studies covering the passage of time over the life course and across generations are needed to operationalize a developmental-contextual career perspective, as well as to adjust career practices to people's needs based on specific lifespan moments and generation cohorts.

The use of the ecological systems theory to organize this literature review presented an unbalanced coverage of the contexts of children's career development, with the microsystem being the most addressed level. This might be 
due to methodological challenges to address increasingly distant levels such as the need for stable human and financial resources. Possibilities to overcome these challenges might include: (a) the management of resources to cover more than one ecological level in a single study (e.g., Ferreira et al., 2007); (b) the use of available information to conduct retrospective studies (e.g., Anyadike-Danes \& McVicar, 2005); (c) the combination of ecological levels in theoretical works that enhance a systemic and comprehensive understanding of children's career development (e.g., Brown, 2004); or (d) the presentation of experience reports that credit indirect systemic influences on children's careers (e.g., Aguiar \& Conceição, 2011; Mouta \& Nascimento, 2008). An unbalanced distribution of quantitative versus qualitative or mixed-method research designs was also found, as the latter methods were only reported in eight reviewed articles. Such an unbalanced distribution is consistent with the more general career literature (Stead et al., 2012). Still, further qualitative or mixed-method studies are needed to address qualitative changes in children's career development and to support the description of this process based on the voices and experiences of children and key figures. These advances would sustain a more accurate organizing framework of children's career development and offer methodological flexibility for its empirical applications and evidence-based practices.

This article suggests two main reasons to support the adoption of an ecological perspective in an organizing framework of children's career development. First, an ecological perspective is included in various existent career theories. Second, an ecological perspective enables the field to move from the identification of main career dimensions and processes (Hartung et al., 2005; Howard \& Walsh, 2010; Skorikov \& Patton, 2007; Watson \& McMahon, 2005) to the identification of ecological subsystems within which the child develops. This has implications for research and practice. As it has been recommended in the human development literature (Tinajero \& Páramo, 2012), career studies may also explicitly indicate the ecological subsystem(s) they are covering. As for intervention, an ecological perspective can lead to the engagement of influential subsystems in the promotion of children's career development (Lent, 2001; Repetto et al., 2007; Schultheiss, 2005). This literature review suggests that career interventions might cover: (a) the microsystem level by empowering parents and teachers; (b) the mesosystem level by promoting collaboration among the child's proximal settings and jointly prepare him/ her for ecological transitions; (c) the exosystem level by promoting the awareness of school principals and community organizations for social justice; (d) the macrosystem level by working with politicians to promote children's ethnical/ cultural competencies and career development throughout the school years; and (e) the chronosystem level by suiting interventions to life-course periods, generations' needs and historical changes.

\section{References}

Aguiar, F. H., \& Conceição, M. I. (2011). Orientação vocacional como tema transversal: Uma experiência com profissionais da educação [Vocational guidance as a cross-curricular theme: An experience with professionals in education]. Revista Brasileira de Orientação Profissional, 12(1), 107-117.

Anyadike-Danes, M., \& McVicar, D. (2005). You'll never walk alone: Childhood influences and male career path clusters. Labour Economics, 12, 511- 530. doi:10.1016/j. labeco.2005.05.008

Araújo, A. M., \& Taveira, M. C. (2009). Study of career development in children from a developmental-contextual perspective. European Journal of Education and Psychology, 2(1), 49-67.

Bayraktar, A. (2011). Possible effects of gender on teacher-student interactions. Procedia Social and Behavioural Sciences, 15, 2545-2548. doi:10.1016/j.sbspro.2011.04.142

Bordin, E. S. (1984). Psychodynamic model for career choice and satisfaction. In D. Brown, L. Brooks \& Associates (Eds.), Career choice and development: Applying contemporary theories to practice (pp. 94-137). San Francisco, CA: JosseyBass.

Bronfenbrenner, U. (1979). The ecology of human development. Cambridge: Harvard University Press.

Bronfenbrenner, U. (1986). Ecology of the family as a context for human development: Research perspectives. Developmental Psychology, 22, 723-742. doi:10.1037//0012-1649.22.6.723

Bronfenbrenner, U., \& Morris, P. A. (1998). The ecology of developmental process. In W. Damon (Series Ed.) \& R. M Lerner (Volume Ed.), Handbook of child psychology: Theoretical models of human development (5th ed., Vol. 1, pp. 993-1028). New York: Wiley.

Brown, M. T. (2004). The career development influence of family of origin: Considerations of race/ethnic group membership and class. The Counseling Psychologist, 32, 587-595. doi:10.1177/0011000004266007

Bryant, B. K., Zvonkovic, A. M., \& Reynolds, P. (2006). Parenting in relation to child and adolescent vocational development. Journal of Vocational Behavior, 69, 149-175. doi:10.1016/j. jvb.2006.02.004

Creed, P. A., Conlon, E. G., \& Zimmer-Gembeck, M. J. (2007). Career barriers and reading ability as correlates of career aspirations and expectations of parents and their children. Journal of Vocational Behavior, 70, 242-258. doi:10.1016/j. jvb.2006.11.001

Derksen, T. (2010). The influence of ecological theory in child and youth care: A review of the literature. International Journal of Child, Youth, and Family Studies, 1(3), 326-339.

Ek, E., Sovio, U., Remes, J., \& Järvelin, M. (2005). Social predictors of unsuccessful entrance into the labour market: A socialization process perspective. Journal of Vocational Behavior, 66, 471486. doi:10.1016/j.jvb.2004.02.002

Ferreira, J. A., Santos, E. J., Fonseca, A. C., \& Haase, R. (2007). Early predictors of career development: A 10-year follow-up study. Journal of Vocational Behavior, 70, 61-77. doi:10.1016/j. jvb.2006.04.006

Fouad, N. A., Hackett, G., Smith, P. L., Kantamneni, N., Fitzpatrick, M., Haag, S., \& Spencer, D. (2010). Barriers and supports for continuing in mathematics and science: Gender and educational level differences. Journal of Vocational Behavior, 77, 361-373. doi:10.1016/j.jvb.2010.06.004 
Fulcher, M. (2011). Individual differences in children's occupational aspirations as a function of parental traditionality. Sex Roles, 64, 117-131. doi:10.1007/s11199-010-9854-7

Gonçalves, C. M., \& Coimbra, J. L. (2007). O papel dos pais na construção de trajetórias vocacionais dos seus filhos [Parents' role in the construction of their children's career]. Revista Brasileira de Orientação Profissional 8(1), 1-17.

Gottfredson, L. S. (1981). Circumscription and compromise: A developmental theory of occupational aspirations. Journal of Counseling Psychology, 28(6), 545-579.

Gottfredson, L. S. (2005). Applying Gottfredson's theory of circumscription and compromise in career guidance and counselling. In S. D. Brown \& R. W. Lent (Eds.), Career development and counselling: Putting theory and research to work (pp. 71-100). New York: Wiley.

Hartung, P. J., Porfeli, E. J., \& Vondracek, F. W. (2005). Child vocational development: A review and reconsideration. Journal of Vocational Behavior, 66, 385-419. doi:10.1016/j. jvb.2004.05.006

Helwig, A. A. (2004). A ten-year study of the career development of students: Summary findings. Journal of Counselling and Development, 82, 49-57. doi:10.1002/j.1556-6678.2004. tb00285.x

Hirschi, A. (2011). Career-choice readiness in adolescence: Developmental trajectories and individual differences. Journal of Vocational Behavior, 79, 340-348. doi:10.1016/j. jvb.2011.05.005

Holland, J. L. (1985). Making vocational choices: A theory of vocational personalities and work environments (2nd ed.). Englewood Cliffs, NJ: Prentice-Hall.

Hong, J. S., \& Garbarino, J. (2012). Risk and protective factors for homophobic bullying in schools: An application of the socialecological framework. Educational Psychology Review, 24, 271-285. doi:10.1007/s10648-012-9194-y

Howard, K. A., Ferrari, L., Nota, L., Solberg, V. S. \& Soresi, S. (2009). The relation of cultural context and social relationships to career development in middle school. Journal of Vocational Behavior, 75, 100-108. doi:10.1016/j.jvb.2009.06.013

Howard, K. A., \& Walsh, M. E. (2010). Conceptions of career choice and attainment: Developmental levels in how children think about careers. Journal of Vocational Behavior, 76, 143-152. doi: 10.1016/j.jvb.2009.10.010

Hughes, J. M. (2011). Influence of discrimination awareness on the occupational interests of African American children. Journal of Applied Developmental Psychology, 32, 369-378. doi:10.1016/j.appdev.2011.08.003

Kendig, S. M., Mattingly, M. J., \& Bianchi, S. M. (2014). Childhood poverty and the transition to adulthood. Family Relations, 63(2), 271-286. doi: 10.1111/fare.12061

Kern, M. L., \& Friedman, H. S. (2008). Early educational milestones as predictors of lifelong academic achievement, midlife adjustment, and longevity. Journal of Applied Developmental Psychology, 30, 419-430. doi:10.1016/j.appdev.2008.12.025

Kingery, J. N., \& Erdley, C. A. (2007). Peer experiences as predictors of adjustment across the middle school transition. Education and Treatment of Children, 30, 73-88. doi:10.1353/ etc. 2007.0007
Kuijpers, M., Meijers, F. \& Gundy, C. (2011). The relationship between learning environment and career competences of students in vocational education. Journal of Vocational Behavior, 78, 21-30. doi:10.1016/j.jvb.2010.05.005

Lent, R. W. (2001). Vocational psychology and career counseling: Inventing the future. Journal of Vocational Behavior, 59, 213 225. doi:10.1006/jvbe.2001.1827

Lent, R. W., Hackett, G., \& Brown, S. D. (2004). Una perspectiva social cognitiva de la transición entre la escuela y el trabajo [A social cognitive perspective on school-to-work transition]. Evaluar, 4, 1-22.

Lerkkanen, M., Kiuru, N., Pakarinen, E., Viljaranta, J., Poikkeus, A., Rasku-Puttonen, H., ... Nurmi, J. (2012). The role of teaching practices in the development of children's interest in reading and mathematics in kindergarten. Contemporary Educational Psychology, 37, 266-279. doi:10.1016/j.cedpsych.2011.03.004

Liu, J., McMahon, M., \& Watson, M. (2014). Childhood career development in Mainland China: A research and practice agenda. The Career Development Quarterly, 62, 268-279. doi:10.1002/j.2161-0045.2014.00084.x

Mello, Z. R. (2009). Racial/ethnic group and socioeconomic status variation in educational and occupational expectations from adolescence to adulthood. Journal of Applied Developmental Psychology, 30, 404-504. doi:10.1016/j.appdev.2008.12.029

Mitchell, L. K., \& Krumboltz, J. D. (1990). Social learning approach to career decision making: Krumboltz theory. In D. Brown, L. Brooks \& Associates (Eds.), Career choice and development: Applying contemporary theories to practice (2nd ed., pp. 145196). San Francisco, CA: Jossey-Bass.

Mouta, A. \& Nascimento, I. (2008). Os (novos) interlocutores no desenvolvimento vocacional de jovens: Uma experiência de consultoria a professores [Teachers as (new) interlocutors in the vocational development of young people: An experience of consultation]. Revista Brasileira de Orientação Profissional, 9(1), 87-101.

Nazli, S. (2007). Career development in primary school children. Career Development International, 12, 446-462. doi:10.1108/13620430710773763

Nazli, S. (2014). Career development of upper primary school students in Turkey. Australian Journal of Guidance and Counselling, 24, 49-61. doi:10.1017/jgc.2013.7

Noack, P., Kracke, B., Gniewosz, B., \& Dietrich, J. (2010). Parental and school effects on students' occupational exploration: A longitudinal and multilevel analysis. Journal of Vocational Behavior, 77, 50-57. doi:10.1016/j.jvb.2010.02.006

Oketch, M., Mutisya, M., \& Sagwe, J. (2012). Parental aspirations for their children's educational attainment and the realization of universal primary education (UPE) in Kenya: Evidence from slum and non-slum residences. International Journal of Educational Development, 32, 764-772. doi:10.1016/j. ijedudev.2011.04.002

Porfeli, E. J., Ferrari, L., \& Nota, L. (2012). Work valence as a predictor of academic achievement in the family context. Journal of Career Development, 40, 371-389. doi:10.1177/0894845312460579

Porfeli, E. J., Wang, C., \& Hartung, P. J. (2008). Family transmission of work affectivity and experiences to children. Journal of Vocational Behavior, 7, 278-286. doi:10.1016/j. jvb.2008.06.001 
Repetto, E., Pena, M., Mudarra, M. J., \& Uribarri, M. (2007). Guidance in the area of socio-emotional competencies for secondary students in multicultural contexts. Electronic Journal of Research in Educational Psychology, 5(1), 159-178.

Roe, A. (1957). Early determinants of vocational choice. Journal of Counseling Psychology, 4, 212-217. doi:10.1037/h0045950

Schmitt-Wilson, S., \& Welsh, M. C. (2012). Vocational knowledge in rural children: A study of individual differences and predictors of occupational aspirations and expectations. Learning and Individual Differences, 22, 862-867. doi:10.1016/j. lindif.2012.06.003

Schoon, I., Martin, P., \& Ross, A. (2007). Career transitions in times of social change. His and her story. Journal of Vocational Behavior, 70, 78-96. doi: 10.1016/j.jvb.2006.04.009

Schuette, C. T., Ponton, M. K., \& Charlton, M. L. (2012). Middle school children's career aspirations: Relationship to adult occupations and gender. The Career Development Quarterly, 60, 36-46. doi:10.1002/j.2161-0045.2012.00004.x

Schultheiss, D. (2005). Elementary career intervention programs: Social action initiatives. Journal of Career Development, 31, 185-194. doi: 10.1177/089484530503100303

Shultheiss, D. (2008). Current status and future agenda for the theory, research, and practice of childhood career development. The Career Development Quarterly, 57, 7-24. doi: 10.1002/ j.2161-0045.2008.tb00162.x

Schultheiss, D., Palma, T., \& Manzi, A. (2005). Career development in middle childhood: A qualitative inquiry. The Career Development Quarterly, 53, 246-252. doi:10.1002/j.2161-0045.2005.tb00994.x

Skorikov, V. B., \& Patton, W. (2007), Career development in childhood and adolescence. Rotterdam: Sense Publishers.

Sobral, J., Gonçalves, C., \& Coimbra. J. (2009). A influência da situação profissional parental no desenvolvimento vocacional dos adolescentes [The influence of parental occupational situation on adolescents' vocational development]. Revista Brasileira de Orientação Profissional, 10(1), 11-22.

Stead, G. B., Perry, J. C., Munka, L. M., Bonnett, H. R., Shiban, A. P., $\&$ Care, E. (2012). Qualitative research in career development: Content analysis from 1990 to 2009. International Journal for Educational and Vocational Guidance, 12, 105-122. doi:10.1007/s10775-011-9196-1

Super, D. E. (1990). A life-span, life-space approach to career development. In D. Brown \& L. Brooks (Eds.), Career choice and development: Applying contemporary theories to practice (2nd ed., pp. 197-261). San Francisco, CA: Jossey-Bass.
Tenenbaum, H. R., Porche, M. V., Snow, C. E., Tabors, P., \& Ross, S. (2007). Maternal and child predictors of low-income children's educational attainment. Journal of Applied Developmental Psychology, 28, 227-238. doi:10.1016/j.appdev.2007.02.002

Tinajero, C., \& Páramo, M. F. (2012). The systems approach in developmental psychology: Fundamental concepts and principles. Psicologia: Teoria e Pesquisa, 28, 457-465. doi:10.1590/S0102-37722012000400011

Tracey, T. J., Lent, R. W., Brown, S. D., Soresi, S., \& Nota, L. (2006). Adherence to RIASEC structure in relation to career exploration and parenting style: Longitudinal and idiothetic considerations. Journal of Vocational Behavior, 69, 248-261. doi:10.1016/j.jvb.2006.02.001

Vondracek, F. W. (2004). Avaliação das relações pessoa-contexto: Plano de um procedimento completo de avaliação dos jovens [Assessment of the person-context interactions: Planning a comprehensive procedure to assess young people]. In L. M. Leitão (Ed.), Avaliação psicológica em orientação escolar e profissional (pp. 429-451). Coimbra: Quarteto.

Vondracek, F. W., Ford, D. H., \& Porfeli, E. J. (2014). A living systems theory of vocational behavior and development. Boston, MA: Sense Publishers.

Vondracek, F. W., Lerner, R. M., \& Schulenberg, J. E. (1986). Career development: A life-span developmental approach. Hillsdale, NJ: Laurence Erlbaum Associates.

Vondracek, F. W., \& Porfeli, E. (2002). Integrating person- and function-centered approaches in career development theory and research. Journal of Vocational Behavior, 61, 386-397. doi: 10.1006/jvbe.2002.1881

Watson, M., \& McMahon, M. (2005). Children's career development: A research review from a learning perspective. Journal of Vocational Behavior, 67, 119-132. doi:10.1016/j. jvb.2004.08.011

Watson, M., McMahon, M., Foxcroft, C., \& Els, C. (2010). Occupational aspirations of low socioeconomic black SouthAfrican children. Journal of Career Development, 37, 717-734. doi:10.1177/0894845309359351

Whiston, S. C., \& Keller, B. K. (2004). The influence of the family of origin on career development: A review and analysis. The Counseling Psychologist, 32, 493-568. doi:10.1177/0011000004265660

Young, R. A. (1983). Career development of adolescents: An ecological perspective. Journal of Youth and Adolescence, 12, 401-417. doi:10.1007/BF02088723 